\title{
SUSCEPTIBILITY OF CERTAIN WHEAT CULTIVARS TO INFESTATION WITH CEREAL APHIDS AND GLASSY CLOVER SNAILS
}

\author{
ADEL M. EL - RAWY \\ Plant Protection Research Institute, ARC. Dokki, Giza, Egypt. \\ (Manuscript received 13 August 2012)
}

\begin{abstract}
Field experiments were carried out at Etay El-Baroud Agric. Res. Station Farm (El-Beheira Governorate) during two successive wheat seasons (2010/11 and 2011/12) to study the relative susceptibility of some wheat cultivars to infestation with cereal aphids and glassy clover snails. The results revealed that, three cultivars; Misr 2, Giza 168 and Gemmeiza 7 had the least infestation by cereal aphids (37.3, 62.2 and 65.2 aphids/10 plants, respectively). On the other hand, three cultivars; Misr 2, Giza 168 and Gemmeiza 11 had the least infestation by glassy clover snails $(5.6,6.0$ and 9.4 snails / $50 \times 50 \mathrm{~cm}^{2}$, respectively). Finally, two cultivars Misr 2 and Giza 168 proved the least infestation by cereal aphids and glassy clover snails.
\end{abstract}

\section{INTRODUTION}

Wheat (Triticum aestivum L.) is the most important grain crop all over the world. In Egypt, it is the main winter cereal crop which gained a particular importance for human consumption. Cultivated in about 3.05 million feddan produced about 8.4 million tons with an average of 18.3 ardab / feddan in 2010/11 season. However, there is still a gap between production and consumption of wheat in the Egypt. Aphid is considered as one of the most serious pests attacking wheat causing damage to the plants either directly by sucking juice or indirectly as a vector of diseases, yield losses due to infestation with aphids differed from 7.5 to $18.7 \%$ (Tantawi,1985).

In recent years, the land snails has became one of the serious pests of wheat. The land snails caused damage to wheat crop by $43.2 \%$ after three months from germination (Mahmoud and Awad, 2008). Because of the cost and the ineffectiveness of controlling wheat pests with insecticides, the wheat breeding program has tried to incorporate varietals resistance for pest infestation into wheat cultivars. 
The aim of the present investigation was to screen certain cultivars for infestation with cereal aphids and glassy clover snails in order to identify new sources of resistance variety.

\section{MATERIALS AND METHODS}

Thirteen bread wheat cultivars were evaluated for resistance to four cereal aphid species and two species of the glassy clover snail, during 2010/11 and 2011/12 seasons.

These cultivars were Sakha 93, Sakha 94, Gemmeiza 7, Gemmeiza 9, Gemmeiza 10, Gemmeiza 11, Misr 1, Misr 2, Giza 168, Sids 1, Sids 12, Sids 13 and Shandaweel 1.All cultivars were sown on Nov. $27^{\text {th }}$ in the first season and Nov.23th in the second season at Etay El-Baroud Agric. Res. Station Farm, El-Beheira governorate.

The aphid species were Rhopalosiphum padi (L.), Schizaphis graminum (Rondani), Rhopalosiphum maidis (Fitch) and Sitobion avenae (Fab.), while the glassy clover snails were Monacha cartusiana (Muller) and Monacha obstructa (Ferussac).

The experimental area was divided into plots $10.5 \mathrm{~m}^{2}$ each, each cultivar was replicated four times in a complete randomized blocks design. All plots received the usual recommended agricultural treatments and no chemicals were used for controlling wheat pests throughout the whole period of the study.

Aphid species and glassy clover snails were counted biweekly on each wheat cultivar along the period from seedling appearance till dryness of the plants. Ten plants were picked up at random from each plot to record number of the cereal aphids. As for snails, two quadrates simple size (50x50 $\mathrm{cm}^{2} /$ quadrate) were randomly chosen; at early morning, from each plot to record their number and all snails found on soil surface in the quadrate were also counted (Baker, 1988). The collected data were statistically analyzed according to Steel et. al.(1997). Analysis of variance were made to determine the significant differences among cultivars. 


\section{RESULTS AND DISCUSSION}

\section{Cereal aphids}

Table (1) shows that the number of cereal aphids in second season (2011/12) was relatively higher than that of first season (2010/11). The different species of aphid found in the wheat field were : The bird cherry-oat aphid $R$. padi represent the highest overall density (49.84\%), followed by greenbug S. graminum $(33.01 \%)$. The least species appeared were english grain aphid S. avenae (12.54\%) and corn leaf aphid $R$. maidis (4.61\%). These results agree with those of Abou-Elhagag and Abdelhafez (1998), Abdel-Aziz et. al. (2002), El-Rawy et. al. (2007) and Khaled and El-Rawy (2012) who stated that the wheat cultivars are usually attacked by a complex of cereal aphid species including $R$. padi, S. graminum, S. avenae and $R$. maidis.

The highest general total mean number of cereal aphid species was recorded on Sakha 93 cultivar (229.8 aphids/10 plants) followed by Sids 13 cultivar (229.4 aphids/10 plants), then Gemmeiza 9 cultivar (199.9 aphids/10 plants) and Misr 1 cultivar (198.3 aphids/10 plants). On the other 
hand, Misr 2, Giza 168 and Gemmeiza 7 cultivars demonstrated the lowest number of cereal aphid species on the basis of general mean of number; 37.3, 62.2 and 65.2 aphids/10 plants, respectively. Several researches were carried out to study genotypic difference in wheat resistance to cereal aphids ( Ali et. al., 1985, Salem and Khalafalla, 1998, Abou-Elhagag and Abdelhafez, 1999, Abdel-Aziz et al., 2002, Ruchira and Sharma, 2002, El-Rawy et. al., 2007 and Khaled and El-Rawy, 2012).

The obtained data in Table (3) reveal that, the total tow seasons mean number of cereal aphids showed a gradual increase perform with 61.6 and 138.4 aphids / 10 plants during January and February, respectively to reach during March its maximum with 206.8 aphids/10 plants then the mean number decline in April to 122.9 aphids / 10 plants. The lowest number which was recorded in January (61.6 aphids/10 plants) , this may be due to the low temperature during this month than the other ones. These results are in agreement with those of Hussien (1993), Abou-Elhagag and Abdelhafez (1998) and Abdel-Aziz et al.(2002) found that the maximum population density of cereal aphids occurred during March on wheat plants, the peak of cereal aphids appeared during this month due to the favorable weather conditions prevailing during this month.

\section{2- Glassy clover snails}

Data illustrated in Table (2) showed that, the number of the glassy clover snails in first season (2010/11) was relatively higher to that of second season (2011/12). The two species of the glassy clover snail in the wheat field were M. cartusiana found in higher density levels (83.56\%) and M. obstructa found in lower density levels (16.44\%). These results agree with those of El-Deeb et. al. (1996), El-Deeb et. al. (1999), Metwally et. al. (2002) and Azzam (2006) who stated that the wheat plants are usually attacked by a complex of glassy clover snails including $M$. cartusiana and M. obstructa .

The highest general mean number of the two species was recorded on Gemmeiza 7 cultivar ( 28.9 snails / $50 \times 50 \mathrm{~cm}^{2}$ ) followed in descending order by Gemmeiza 9 cultivar (25.0 snails), then Sakha 93 cultivar (21.1 snails) and Shandaweel 1 cultivar (19.7snails). On the other hand, Misr 2, Giza 168 and Gemmeiza 11 cultivars demonstrated the lowest numbers of the two species on the basis of general mean of numbers $\left(5.6,6.0\right.$ and 9.4 snails / $50 \times 50 \mathrm{~cm}^{2}$, respectively).

Data in Table (3) reveal that, the number of the two species of glassy clover snail showed a gradual increase to reach 29.2 snails / $50 \times 50 \mathrm{~cm}^{2}$ during April followed downwards by March ( 23.0 snails / $50 \times 50 \mathrm{~cm}^{2}$ ), then February (12.5 snails / $50 \times 50 \mathrm{~cm}^{2}$ ). While the lowest numbers were recorded in December and January (2.9 
and 5.0 snails / $50 \times 50 \mathrm{~cm}^{2}$, respectively), this may be due to the low temperature during these months than the other ones. These results are in agreement with those obtained by El-Deeb et al.(1996), El-Deeb et. al. (1999), Metwally et. al. (2002) and Mahmoud and Awad (2008), they mentioned that the highest population density of land snails was observed during April on wheat plants due to the suitable climatic conditions during this month.

A short glance to the data in Tables (1 and 2) reveals that, two cultivars Misr 2 and Giza 168 proved least infestation by cereal aphids and glassy clover snails.

Table 2. Annually mean numbers of M.cartusiana and M. obstructa / 50 x $50 \mathrm{~cm}^{2}$ of wheat cultivars , 2010/11 and 2011/12 seasons .

\begin{tabular}{|c|c|c|c|c|c|c|c|c|c|}
\hline \multirow[b]{2}{*}{ Cultivar } & \multicolumn{3}{|c|}{$2010 / 11$} & \multicolumn{3}{|c|}{$2011 / 12$} & \multicolumn{3}{|c|}{ Mean } \\
\hline & $\begin{array}{c}\text { M. } \\
\text { cartusiana }\end{array}$ & $\begin{array}{c}M . \\
\text { obstructa }\end{array}$ & Total & $\begin{array}{c}M . \\
\text { cartusiana }\end{array}$ & $\begin{array}{c}\text { M. } \\
\text { obstructa }\end{array}$ & Total & $\begin{array}{c}\text { M. } \\
\text { cartusiana }\end{array}$ & $\begin{array}{c}\text { M. } \\
\text { obstructa }\end{array}$ & Total \\
\hline Sakha 93 & 20.0 & 4.7 & $24.7 \mathrm{bc}$ & 14.5 & 2.9 & $17.4 \mathrm{c}$ & 17.3 & 3.8 & $21.1 \mathrm{c}$ \\
\hline Sakha 94 & 14.3 & 2.6 & $16.9 \mathrm{~d}$ & 9.7 & 1.5 & $11.2 \mathrm{~d}$ & 12.0 & 2.1 & $14.1 \mathrm{~d}$ \\
\hline Gemmeiza 7 & 25.2 & 6.5 & $31.7 \mathrm{a}$ & 21.9 & 4.1 & $26.0 \mathrm{a}$ & 23.6 & 5.3 & $28.9 \mathrm{a}$ \\
\hline Gemmeiza 9 & 24.4 & 3.4 & $27.8 \mathrm{~b}$ & 18.5 & 3.6 & $22.1 \mathrm{~b}$ & 21.5 & 3.5 & $25.0 \mathrm{~b}$ \\
\hline Gemmeiza 10 & 15.5 & 2.8 & $18.3 \mathrm{~d}$ & 7.7 & 1.9 & $9.6 \mathrm{de}$ & 11.6 & 2.4 & $14.0 \mathrm{~d}$ \\
\hline Gemmeiza 11 & 10.2 & 1.5 & $11.7 \mathrm{e}$ & 6.1 & 1.0 & $7.1 \mathrm{ef}$ & 8.2 & 1.2 & $9.4 \mathrm{ef}$ \\
\hline Misr 1 & 12.1 & 2.5 & $14.6 \mathrm{e}$ & 8.4 & 1.5 & $9.9 \mathrm{de}$ & 10.3 & 2.0 & $12.3 \mathrm{de}$ \\
\hline Misr 2 & 5.0 & 0.8 & $5.8 \mathrm{f}$ & 4.9 & 0.5 & $5.4 \mathrm{f}$ & 5.0 & 0.6 & $5.6 \mathrm{f}$ \\
\hline Giza 168 & 6.2 & 1.0 & $7.2 \mathrm{f}$ & 3.9 & 0.8 & $4.7 \mathrm{f}$ & 5.1 & 0.9 & $6.0 \mathrm{f}$ \\
\hline Sids 1 & 10.5 & 2.0 & $12.5 \mathrm{e}$ & 6.4 & 1.3 & $7.7 \mathrm{def}$ & 8.5 & 1.6 & $10.1 \mathrm{e}$ \\
\hline Sids 12 & 11.8 & 2.2 & $14.0 \mathrm{e}$ & 9.0 & 1.4 & $10.4 \mathrm{de}$ & 10.4 & 1.8 & $12.2 \mathrm{de}$ \\
\hline Sids 13 & 12.0 & 2.4 & $14.4 \mathrm{e}$ & 6.3 & 1.1 & 7.4 def & 9.1 & 1.8 & $10.9 \mathrm{de}$ \\
\hline Shandaweel 1 & 18.3 & 4.2 & $22.5 \mathrm{c}$ & 13.7 & 3.1 & $16.8 \mathrm{c}$ & 16.0 & 3.7 & $19.7 \mathrm{c}$ \\
\hline Mean & 14.3 & 2.8 & - & 10.1 & 1.9 & - & 12.2 & 2.4 & - \\
\hline$\%$ Population & 83.63 & 16.37 & - & 84.17 & 15.83 & - & 83.56 & 16.44 & - \\
\hline LSD 0.05 & & & 3.74 & & & 3.91 & & & 3.85 \\
\hline
\end{tabular}

Mean followed by the same letter(s) in each column within each treatment are not significantly differed. 
Table 3 . Population density of aphids and glassy clover snails , 2010/11 and 2011/12

\begin{tabular}{|c|c|c|c|c|c|c|}
\hline \multirow[b]{2}{*}{ Months } & \multicolumn{3}{|c|}{ Aphids / 10 plants } & \multicolumn{3}{|c|}{ Glassy clover snails $/ 50 \times 50 \mathrm{~cm}^{2}$} \\
\hline & $2010 / 11$ & $2011 / 12$ & Mean & $2010 / 11$ & $2011 / 12$ & Mean \\
\hline December & - & - & - & 3.8 & 2.0 & $2.9 \mathrm{~d}$ \\
\hline January & 22.4 & 100.8 & $61.6 \mathrm{~d}$ & 6.3 & 3.8 & $5.0 \mathrm{~d}$ \\
\hline February & 126.0 & 150.9 & $138.4 \mathrm{~b}$ & 14.4 & 10.6 & $12.5 \mathrm{c}$ \\
\hline March & 192.4 & 221.3 & $206.8 \mathrm{a}$ & 27.6 & 18.4 & $23.0 \mathrm{~b}$ \\
\hline April & 115.2 & 130.6 & $122.9 \mathrm{c}$ & 33.4 & 25.0 & $29.2 \mathrm{a}$ \\
\hline General mean & 114.0 & 150.9 & - & 17.1 & 12.0 & - \\
\hline LSD 0.05 & & & 11.5 & & & 3.7 \\
\hline
\end{tabular}

Mean followed by the same letter(s) in each column within each treatment are not significantly differed.

\section{ACKNOWLEDGEMENT}

Deep thanks to Prof. Dr. Karima M. Azzam from Plant Protection Research Institute, Agric. Res. Center, Dokki, Giza for the identification of the collected snails.

\section{REFERENCES}

1. Abdel-Aziz, M.A., A.A. Abdel-Alim, N. Abdel-Aziz and G.A. Morsi. 2002. Susceptibility of different wheat varieties to infestation to cereal aphids with reference to safe control approach. 2 nd International Conf., Plant Protection Res. Institute, Cairo, Egypt, 21 - 24 December 2 : 685 - 690.

2. Abou-Elhagag, G.H. and N.A. Abdelhafez. 1998. Cereal aphids (Homoptera:Aphididae) : factors affecting their populations on wheat in Upper Egypt. Assiut J. Agric. Sci. 29 (3) : $241-252$.

3. Abou-Elhagag, G.H. and N.A. Abdelhafez. 1999. Susceptibility of some wheat cultivars to infestation with cereal aphids in Upper Egypt. Assiut J. Agric. Sci. 30 (3) : $1-11$.

4. Ali, A.A., A.S. Rajab and H. Al-Hussiani. 1985. Relative Susceptibility of different wheat varieties to aphid infestation. J. Agric. and water Resources Res. $4: 25$ 39.

5. Azzam Karima, M. 2006. Survey on terrestrial gastropods their host plants and parasitic nematodes as biocontrol agents. J. Egypt. Ger. Soc. Zool. (49D) : 49 61. 
6. Baker, G.H. 1988. The life history, population dynamic and polymorphism of Cernuella virgate (Mollusca : Helicidae). Aust. J. Zool. $36: 497$ 512.

7. El-Deeb, H.I., E.M. Ghamry, N. El-Hawashy and N.H. Essa. 1996. Relative abundance of some land snails in certain Governorates of Egypt. J. Agric., Sci. Mansoura Univ. 21(8) : 2922 - 2983.

8. El-Deeb, H.I., M. Wilison and E.H. Eshra. 1999. Ecological studies on certain land snails infest some economic crops at Beheira governorate, Egypt. 2nd Int. Conf. of Pest Control, Mansoura, Egypt : $19-28$.

9. El-Rawy, A.M., M.A. Khaled and S.M. Osman. 2007. Impact of NPK fertilizers, wheat varieties and their interactions on the infestation with cereal aphids and leafminer, yield and its components. J. Agric. Sci. Mansoura Univ. 32 (4) : $3113-3122$.

10. Hussien, I. A. A.1993. Abundance dynamics of cereal aphids (Hom. Aphididae) and their natural enemies antagonists on different wheat types in Dier Ezzor (Syrian Arab Rep.). Archives of Phytopathology and Plant Protection 28 (5) : 439 445.

11. Khaled, M.A. and A.M. El-Rawy. 2012. Influence of some seeding and nitrogen rates on grain yield and insect natural infestation of some wheat cultivars. Egypt. J. Agric. Res. 90 (3) : 1169 - 1187.

12. Mahmoud, M.F. and M.H.Awad. 2008. Population density of certain land snail and slug species and their damage to some fields and vegetable crops. Egypt. J. Agric. Res. 86 (5) : 1763 - 1772.

13. Metwally, A.M., H.A. Zedan, A.B. El-Saeid and T.M.M. El-Akra. 2002. Ecological studies on certain land snails in Monofia and Gharbia Governorates. 2nd Int. Conf., Plant Protection Res. Institute, Cairo, Egypt, 21 - 24 December 1: 70 - 79.

14. Ruchira, T. and V.K. Sharma. 2002. Relative susceptibility of wheat germplasme to aphids. Indian J. Entomol. 64 (3) : 324 - 329.

15. Salem, R.M. and E.M.E. Khalafalla. 1998. Relative susceptibility of certain wheat cultivars to infestation with the bird cherry-oat aphid Rhopalosiphum padi (L.). Alex. Sci. Exch. 19 (1) : $17-23$.

16. Steel, R.G.D., J.H. Torrie and D.A. Dickey. 1997. Principles and procedures of statistics. 3rd Ed. McGraw-Hill Book Co., INC. NY, USA,166pp.

17. Tantawi, A.M. 1985. Studies on wheat aphids in Egypt. II- Germplasm evaluation and crop loss assessment. Rachis 4 (2) : $26-27$. 
قابلية بعض أصناف القمح للإصابة بالمن وقوقع البرسيم الزجاجي عادل محمد الز اوي

معجة بحوث وقاية النباتات - مركز البحوث الزراعية - الدقي - حيزة - مصر.

أجريت التجارب بمزرعة محطة البحوث الزر اعية بأيتاي البارود ( البحيرة)

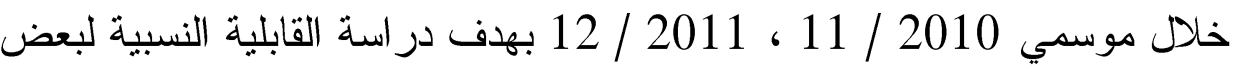
أصناف القمح للإصابة بالمن وقوقع البرسيم الزجاجي .

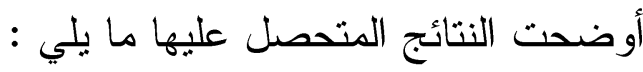

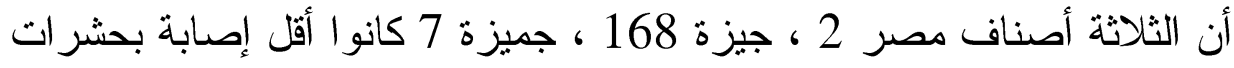
المن ( 37.3 ، 62.2 ، 65.2 حشرة من / 10 نباتات بالترتيب ) و على الجانب الأخر وجد أن الثلاثة أصناف مصر 2 ، جيزة 168 ، جميزة 11 كانو أقل إصابة

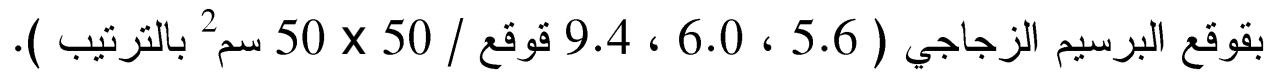
وكنتيجة نهائية لهذا البحث فقد وجد أن صنفي القمح مصر 2 ، ، جيزة 168 كانا

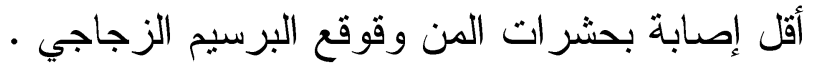

